Espacio, Tiempo y Forma, Serie VII, H. ${ }^{a}$ del Arte, t. 20-21, 2007-2008, págs. 85-112

\title{
De pintor a noble caballero: Los cambios de la imagen de Velázquez en las Vidas de Pacheco a Palomino
}

\section{From being a painter to be a noble Knight: The changes in the image of Velázquez in the «Lifes of Velázquez», by art Theorists Pacheco to Palomino}

\author{
KARIN HELLWIG*
}

\section{RESUMEN}

En la creación de las «imágenes» de Velázquez por los tratadistas Pacheco,

Díaz del Valle, Martínez y Palomino asistimos a unos grandes cambios, debidos a los diferentes objetivos marcados por los escritos. Pacheco (1638) lo presenta como "grande retratador» al lado de los grandes maestros Ticiano y Rubens y como "Apeles español», apoyando sus esfuerzos por obtener mayores premios y honores. Con el propósito de avalar sus pretensiones de ingresar en la Orden de

Santiago, su amigo y colega Díaz del Valle (1659) amplía esta imagen a la de un Velázquez "caballero», "pintor y arquitecto» $y$ "divino artista». No menos remarcable es la imagen de "gran pintor»

\begin{abstract}
In the «images» of Velázquez created by the art theorists Pacheco, Díaz del Valle, Martínez and Palomino we can emphasize some great changes depending on the aims of each one. Pacheco (1638) is presenting the artist as «grande retratador» ("great portraitist») next to Tizian and Rubens and as «Apeles español", pointing out his efforts to obtain some day more awards and honours. Supporting the ambicious bids for being awarded with the Order of the Knights of Santiago, his friend and colleague Díaz del Valle (approx. 1659) amplifies this image to one of Velázquez «caballero» («knight»), "pintor y arquitecto" («painter and arquitect») and "divino artista" («divine artist»). Not less remarkable is the
\end{abstract}

* Zentralinstitut für Kunstgeschichte. Munich. E-mail: k.hellwig @ zikg.eu 
creada por Jusepe Martínez (1673) unos

diez años más tarde, queriendo así encarar el menosprecio general de que era objeto la pintura española dentro y fuera de las fronteras. En esa gran escala de imágenes, Palomino enfatiza la imagen del pintor como «noble caballero». Velázquez será el único artista en su Parnaso español pintoresco laureado (1724) del que el tratadista oculte su condición de pintor y le convierta en el paradigma del cambio del estatus de la pintura, que pasa de mero "oficio» a "arte liberal y noble».

PALABRAS CLAVE

Velázquez, Pacheco, Díaz del Valle, Martínez, Palomino, imagen de artista, literatura de vidas, teoría de arte. image of Velázquez "gran pintor» («great painter») created by Jusepe Martínez (about 1673) a decade later, in the context to counteract the underestimation of the spanish painting not only abroad but also in Spain. To this big scale of images Palomino is adding a new accent, emphasizing the image of the artist as «noble caballero» («noble knight»). Velázquez is the only artist in the Parnaso español pintoresco laureado (1724) whose profession of "pintor» is to some extent hidden. For the theorist the fortunate career of Velázquez at the court of Philip IV from «pintor» to "noble caballero" marks a paradigma of the change of the state of painting from an "oficio" ("handcraft») to an "arte liberal y noble» («noble and liberal profession»).

\section{KEYWORDS}

Velázquez, Pacheco, Díaz del Valle, Martínez, Palomino, image of artist, lives of artists, art theory.

Una aproximación a las vidas de Diego Velázquez escritas por Francisco Pacheco, Lázaro Díaz del Valle, Jusepe Martínez y Antonio Palomino, centrada en la imagen del artista que los tratadistas nos facilitan, muestra los sorprendentes cambios que sufre la biografía del pintor sevillano'. En los casi 80 años que sepa-

1 Quería agradecer especialmente a Amaya Alzaga sus sugerencias y su ayuda en la redacción del texto. Para el tema de la imagen de Velázquez en la literatura artística del siglo XVII, véase AYALA, F., «Velázquez», en Veintitrés biografías de pintores. Museo del Prado, Madrid, Mondadori 1992, págs. 275289; HELLWIG, K., La literatura artística española del siglo xVII, Madrid, Visor, 1999. Además hay aportaciones en las introducciones y las notas de las ediciones críticas de las vidas de Pacheco, Martínez y Palomino. Véase PACHECO, F., El Arte de la Pintura, ed. Bonaventura Bassegoda y Hugas, Madrid, Cátedra, 1990; MARTínEZ, J. Discursos practicables del nobilisimo Arte de la Pintura, ed. María Elena Manrique Ara, Madrid, Cátedra, 2006; PALOMINO, A., Vidas, ed. Nina Ayala Mallory, Madrid, Alianza, 1986; PALOMINO, A., Vida de Don Diego Velázquez de Silva, ed. Miguel Morán Turina, Madrid, Akal, 2008. La vida completa de Velázquez de Lázaro Díaz del Valle comentada figura en la tesis doctoral de José María Riello Velasco, Universidad Complutense, Madrid, 2008, inédita hasta el momento. Para el texto de la vida de Velázquez de Díaz del Valle, véase DíAZ DEL VALLE, L., «Epílogo y nomenclatura de algunas hombres famosos en esta arte", en Varia Velazqueña, ed. Antonio Gallego y Burín, tomo II, Madrid, 1960, págs. 59-61. 
De pintor a noble caballero: Los cambios de la imagen de Velázquez en las Vidas...

ran la redacción de los textos, cada uno de los cuatro tratadistas crea o enfatiza su propia imagen del artista. Cierto es que, tanto la obra y el género de sus cuadros - los numerosos retratos de la familia real, las escasas historias-, como su exitosa carrera desarrollada en la corte de Felipe IV juegan un papel clave en las apreciaciones del artista ${ }^{2}$. Cierto es también que cada uno de los autores destaca una imagen de Velázquez en concordancia con los objetivos de su tratado, como, en el caso de sus contemporáneos, apoyar al artista en su carrera cortesana.

\section{FRANCISCO PACHECO: VELÁZQUEZ COMO GRAN RETRATISTA $Y$ APELES ESPAÑOL}

Pacheco incluye la vida de Velázquez en su tratado Arte de la Pintura (Fig. 1) (acabado en 1638 y publicado en 1649), en el capítulo «De otros famosos pintores deste tiempo, favorecidos con particulares honras por la pintura» ${ }^{3}$. En la vida de su yerno menciona solamente nueve obras concretas, todas ellas retratos ${ }^{4}$. El tratadista alude también a una serie de obras sin especificar. Relata cómo el joven Velázquez dibujó a un muchacho en diversas acciones y posturas. Destaca además unos bodegones como «principios", por lo que podemos concluir que pertenecen a la etapa sevillana del pintor. También hace referencia a dibujos según el «Juicio final» de Miguel Ángel y pinturas de Rafael en el Vaticano, realizados durante la primera estancia de Velázquez en Roma en 1629-1631.

Pacheco enfatiza la gran calidad de los retratos de Velázquez al alabarlos con palabras como «tan al natural» $»^{5}$ « lindo» ${ }^{6}$. Al mismo tiempo, destaca la alta consideración que reciben los retratos del sevillano entre el público: el retrato de Góngora fue «muy celebrado» y su primer retrato de Felipe IV de 1623 provocó tanta admiración en la corte que el Conde Duque afirmó «no haber retratado el rey hasta entonces» ${ }^{7}$. Sobre el retrato ecuestre del rey refiere que fue expuesto en la calle Mayor «con admiración de toda la corte e envidia de los de l'arte» 8 y comen-

2 La obra hoy conservada atribuída a Velázquez cuenta entre 100 y 120 cuadros, de los cuales sólo unos 20 son cuadros de historia.

3 Véase PACHECO, F., Op. cit., págs. 516-533.

4 Se trata del retrato de Luis de Góngora, el de Juan de Fonseca, dos retratos de Felipe IV - uno de ellos a caballo-, uno del Príncipe de Gales, un «Retrato de Felipe III y la expulsión de los moriscos», un autorretrato, un retrato de la Reina de Hungría hecho en Nápoles y un retrato del príncipe Baltasar Carlos.

5 Sobre el retrato de Felipe IV a caballo hecho en 1626 señala que fue «imitado todo del natural». Véase PACHECO, F., Op. cit., pág. 205.

6 Menciona por ejemplo el «lindo retrato de la Reina de Hungria». Véase PACHECO, F., Op. cit., pág. 209.

7 Véase PACHECO, F., Op. cit., págs. 203-204.

8 Véase PACHECO, F., Op. cit., pág. 205. 
givo

LIBRO PRIMERO

A DIEGO DE SILVA VELAZQVEZ,

Pintor de nuestro Catolica Rei Filipo cuarto, abiêdo pints. do fu Retrato a Cavallo, le of recio fu Juegro

Francif6o Pacheco, estando en

Madrid, ente Soneto.

Q Vela, jovenvaliente, en leventura

de tu raroprincipio, la privança

onre la poffefion, no la efperança, d'el lugar que alcançafte en la Pintura.

Angimetel Augúfta alti figura

d' el Monarca major qu' el Orbe alcança,

en cuyo a pecto teme la mudança

aquel que tanta luz mirar procura.

Al calor d'efte Soltiempla tu buelo,

i veras cuanto eftiende tu memoria

la Fama, for tuingenioi tus pinzeles:

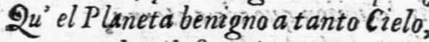
tu nombre iluftrar â con nueva gloria, pues es mas que Alexandro, $i$ tu fu Apeles.

$C A P . I X . D E$ LOS NOBLESI

Santos que exercitaron la Pintura, ide algunos efectos maravillojos procedidos della.

$\mathrm{E}$

Stas onras i favores (que hafta aqui ąvemos contado]no las alcançan los ordinarios pintores, aunque fean ricos: por fer premios devidos a los eftudios, de que ellos vo luntariamente fe privaron: fibien vemos que fe amparan a la fo bra defta Arte. A cuyos profeffores (como fe à vifto) no folo onf2-

Fig. 1. Vida de Velázquez, en: Francisco Pacheco, Arte de la Pintura, Sevilla 1649.

ta el autorretrato de Velázquez hecho en Roma como «famoso retrato suyo [...] para admiración de los bien entendidos y honra de l'arte"?.

Pero Pacheco subraya también la gran calidad de los retratos velazqueños al mencionarlos al lado de los retratos de famosos maestros europeos, como el autorretrato del pintor «hecho en Roma y pintado con la manera del gran Ticiano y no

9 Véase PACHECO, F., Op. cit., pág. 208. 
De pintor a noble caballero: Los cambios de la imagen de Velázquez en las Vidas...

inferior a sus cabezas» ${ }^{10}$. Según el tratadista, su yerno obtiene casi todos los premios, recompensas y títulos, como gratificación por sus extraordinarios retratos reales: es nombrado Pintor del Rey, Ujier de Cámara, Ayuda de Guardarropa y Ayuda de Cámara.

Sorprende la alta valoración que concede Pacheco al retrato, que se evidencia ya en el título del capítulo sobre este género - «De la pintura de animales y aves, pescaderías y bodegones y de la ingeniosa invención de los retratos» - , incluyéndolos así entre las “cosas mayores»11. Al mismo tiempo, la tradicional correspondencia entre ingenio y dibujo, o práctica y color, influye en su jerarquía de los géneros pictóricos. Por supuesto el tratadista relativiza su valoración cuando recuerda que los grandes maestros como Miguel Ángel, Correggio, Caravaggio, Tintoretto o Navarrete El Mudo, aspiraban a algo más alto y complicado que los retratos, decantándose por la historia. $Y$ en sus reflexiones subraya también que la fama de Apeles, Rafael o Tiziano no se debe a sus retratos sino a sus historias. Sin embargo el alto aprecio del retrato en Pacheco, se evidencia en que, además de los «grandes pintores» dedicados a la historia, destaca a los «grandes retratadores», entre los que sobresalen los pintores españoles, con Velázquez a la cabeza. Mientras que los «grandes pintores» fueron «grandes retratadores», no ocurre así a la inversa para el tratadista.

\section{2. «LA EXPULSIÓN» COMO RETRATO DE FELIPE III, VELÁZQUEZ GRANDE RETRATADOR}

Pacheco presenta a Velázquez como un retratista puro que —en sus «principios»-, había pintado algún bodegón ${ }^{12}$, pero no se refiere a ninguna de sus historias. Resulta llamativo que el tratadista no mencione ninguno de los cuadros de historia de Velázquez, ni los romanos la «Túnica de José» y la «Fragua de Vulcano», ni el «Baco», de los que sin embargo tenía información. El único cuadro de historia al cual hace referencia es el de la «Expulsión de los moriscos por Felipe III», de 1627, con el que el pintor ganó el concurso contra Angelo Nardi, Vicente Carducho y Patricio Cajés, y resulta llamativo que el tratadista se refiera a esta composición como un «retrato». Pacheco comenta poco el certamen entre los pintores de corte. Menciona solamente que Velázquez hizo este cuadro «en oposicion de tres pintores del Rey» y que aventajó a todos, sin nombrar a los vencidos. Sin embargo, hace referencia a los dos artistas cortesanos que juzgaron los cua-

10 Véase PACHECO, F., Op. cit., pág. 235.

11 Véase PACHECO, F., Op. cit., págs. 516-533. Sobre la valoración de los géneros de pintura en la tratadistica española del siglo XVII, véase HELLWIG, K., Op. cit. 1999, págs. 253-282.

12 Véase PACHECO, F., Op. cit., pág. 519. 
dros, el marqués Juan Bautista Crescenzi, del hábito de Santiago y el fraile Juan Bautista Maíno, del hábito de Santo Domingo. De hecho, estos dos artistas de gran crédito, el uno caballero noble y de hábito, el otro fraile, son los únicos artistas activos en España - además de él mismo como maestro- a los cuales se refiere Pacheco en la vida de Velázquez. Llama la atención la alusión al cuadro de la expulsión de los moriscos como «Retrato del Rey Felipo III y la no esperada expulsión de los moriscos», como un «retrato» y no como una «historia». En otra ocasión interpretamos que el tratadista, al designar como retrato un cuadro de historia, pretendía revalorizar dicho género ${ }^{13}$.

Pero si releemos el texto desde el trasfondo de la problemática de los géneros, se plantea una segunda interpretación. A Pacheco no le convenía presentar a Velázquez como un "gran pintor» equiparable en rango a Rafael, Miguel Ángel o Tiziano, creadores todos de un gran corpus de historias, frente a las escasas composiciones del sevillano. Por este motivo renuncia a mencionar los pocos cuadros de historia y se centra en presentar a su yerno como un extraordinario retratista de corte, incluyéndolo así en la lista de los «grandes retratadores». En vez de añadir el cuadro de la «Expulsión» como historia a la obra de Velázquez, el tratadista prefiere presentarlo como un retrato real de Felipe III, de gran tamaño e importancia. Su significado especial radica en su ejecución por oposición a tres pintores reales. Velázquez les había "aventajado a todos", como calificaron los dos artistas de corte Crescenzi y Maíno, a quienes el tratadista sevillano concede «gran conocimiento en la pintura». Esta renuncia se puede interpretar como una táctica muy refinada, considerando que Pacheco intentaba apoyar con su tratado los esfuerzos de su yerno por alcanzar un rango superior de cortesano y obtener numerosos órdenes y premios. Por lo tanto, el objetivo del tratadista sería el de crear una imagen muy amplia del artista como retratista real. No le era posible incluir por aquel entonces a Velázquez, que apenas tenía 40 años y que había pintado pocos cuadros de historia, en la categoría de los «grandes pintores». Pero sí que le podía ensalzar, en base a su actividad como pintor de excelentes retratos, como "grande retratador». Esta interpretación explicaría por qué Pacheco consideró la «Expulsión de los moriscos por Felipe III» un retrato y omitió los otros cuadros de historia de su yerno. Así, Velázquez figura al lado de Tiziano en la categoría de los grandes retratistas europeos.

Además de presentar a Velázquez como "grande retratador» Pacheco construye - sin declararlo abiertamente - recurriendo a una serie de topoi, la figura del pintor como «Apeles español» "14. Elabora unas vidas paralelas de Velázquez y Apeles, conforme a las noticias de Plinio, basándose en la carrera y obra de ambos

13 Véase HELLWIG, K., Op. cit. 1999, págs. 268-270.

14 Véase HELLWIG, K., Op. cit. 1999, págs. 137-144. 
pintores ${ }^{15}$. La relación paradigmática entre un príncipe y un pintor como Alejandro Magno y Apeles tiene su correlato en la estrecha relación entre Velázquez y Felipe IV. Ambos son retratistas reales y la promesa de Olivares a Velázquez de que sólo él tendría el privilegio de retratar al rey remite igualmente al ejemplo de la Antigüedad, cuando Alejandro había permitido sólo a Apeles hacer su retrato. Como su precursor griego, también Velázquez exponía públicamente sus obras, para que fueran juzgadas - exhibió el retrato ecuestre en la calle Mayor frente a San Feli$p e^{16}$. Y por fin encontramos en la vida de Velázquez un concurso en oposición a los pintores del Rey en $1627^{17}$, que se corresponde con el certamen de Apeles y Protógenes. Otro paralelismo entre la vida de Velázquez y las noticias que Plinio transmite sobre Apeles es que ambos hicieron un autorretrato famoso ${ }^{18}$. Además de estos topoi y equivalencias mencionadas, Pacheco no usa de modo explícito la metáfora de Velázquez como Apeles español, que sí aparece en los dos elogios que siguen a la vida del pintor en su tratado. Así Jerónimo González de Villanueva compara en su soneto sobre un retrato ecuestre de Felipe IV al caballo del rey con Bucéfalo, el corcel de Alejandro ${ }^{19}$. Pacheco a su vez formula literalmente en el soneto dedicado a su yerno el paralelo entre Alejandro-Apeles y Felipe IV-Velázquez.

Además de presentar a Velázquez como «Apeles español», Pacheco intenta incluir a su yerno en la categoría de los "grandes maestros» europeos. Con este fin centra su relato en la carrera en la corte madrileña y su éxito en Roma. Llama la atención que el tratadista no mencione en la vida ninguna obra de Velázquez hecha en Sevilla. Remarca solamente en otra ocasión que el artista tuvo sus «principios" pintando bodegones valientes de gran aprecio y se centra en cuadros pintados en Madrid y en Roma. El motivo de esta renuncia a mencionar cuadros de la etapa sevillana, que evidentemente le eran familiares, es obvio: Pacheco no quiso presentar a su yerno como un pintor provinciano de bodegones e historias religiosas, sino como un exitoso retratista de corte de rango europeo. De esta forma alude a la gran calidad del autorretrato «hecho en Roma y pintado con la manera del gran Tiziano y no inferior a sus cabezas» ${ }^{20}$ y la alta estimación que se le concedió durante su estancia en Roma. De igual manera Pacheco no destaca relaciones del artista con pintores sevillanos o madrileños, sino solamente con artistas de categoría europea. En la vida de Rubens menciona su limitado trato amistoso con artistas durante su segunda estancia en la corte madrileña en 1628-29: «Con

15 Véase PLINIO, libro 35.

16 Véase PACHECO, F., Op. cit., pág. 205. El retrato ecuestre de Alejandro pintado por Apeles también fue expuesto a la crítica del público.

17 Véase PACHECO, F., Op. cit., pág. 206.

18 Véase PACHECO, F., Op. cit., pág. 208.

19 Véase PACHECO, F., Op. cit., págs. 210-212.

20 Véase PACHECO, F., Op. cit., pág. 532. 
pintores comunicó poco, sólo con mi yerno (con quien se había antes por cartas correspondido) hizo amistad, y favoreció mucho sus obras por su modestia, y fueron juntos a ver el Escorial» ${ }^{21}$. Acentuando la amistad de los dos pintores y la alta estima en que el famoso Rubens tuvo a Velázquez, el tratadista nos presenta a su yerno dentro de una tradición de "artistas nobles» que habían trabajado al servicio de príncipes y obtenido sus merecidas honras.

Llama asimismo la atención que Pacheco incluya en el citado capítulo «De otros famosos pintores deste tiempo, favorecidos con particulares honras por la pintura" solamente las vidas de tres artistas: Diego de Romulo Cincinatto, Pedro Pablo Rubens y Velázquez ${ }^{22}$. Recordemos que los dos primeros fueron caballeros de hábito. Como el mismo Pacheco subraya en el título, su objetivo no es ofrecer el mayor número posible de datos biográficos de los tres artistas, sino documentar las «honras» extraordinarias por ellos recibidas. Nos informa que Cincinatto fue ennoblecido en la Roma del papa Urbano VIII, quién le concedió el hábito de Cristo23. De Rubens nos presenta su afortunada carrera como pintor al servicio de los príncipes europeos, el Archiduque de Flandes, el rey de Inglaterra, el emperador y Felipe IV y acaba el párrafo mencionando, como culminación de las honras recibidas, que Carlos I «le armó tercera vez caballero» ${ }^{24}$. Del mismo modo subraya en la vida de Velázquez las honras y los premios recibidos en la corte madrileña y el tratamiento especial del que fue objeto en Roma. Menciona en varias ocasiones la alta estimación en que Felipe IV tuvo al pintor cuando nos informa que «de su mano liberal ha recibido y recibe tantos favores» ${ }^{25}$. En otro contexto indica la «liberalidad y agrado con que es tratado de un tan gran Monarca" que le ha concedido "tantas mercedes» ${ }^{26}$. Una posible alusión de Pacheco a los tempranos intentos de Velázquez de obtener un hábito de caballero la encontramos en su comentario de los grandes premios y honores recibidos, entre otros el oficio de Ayuda de Guardarropa y de Ayuda de Cámara, "cosa que desean muchos caballeros de hábito "27. La intención obvia del tratadista sevillano de apoyar con el Arte de la pintura las pretensiones de Velázquez de obtener del rey en lo sucesivo mayores honores e incluso un nombramiento de caballero, se evidencia en la confianza e ilusión que destila la frase final de la vida del artista: «esperamos el aumento y las mejoras [...] en los favores y premios debidos a su buen ingenio' ${ }^{28}$.

21 PACHECO, F., Op. cit., pág. 202.

22 Véase PACHECO, F., Op. cit., págs. 192-213.

23 Véase PACHECO, F., Op. cit., pág. 193.

24 Véase PACHECO, F., Op. cit., pág. 202.

25 Véase PACHECO, F., Op. cit., pág. 203.

26 Véase PACHECO, F., Op. cit., pág. 209.

27 Véase PACHECO, F., Op. cit., pág. 209.

28 Véase PACHECO, F., Op. cit., pág. 209. 


\section{LÁZARO DÍAZ DEL VALLE: VELÁZQUEZ COMO ARQUITECTO, CABALLERO Y DIVINO ARTÍFICE}

A esa imagen de Velázquez como «grande retratista« y «Apeles español» construida por Pacheco, añade algo el músico y genealogista de corte Lázaro Díaz del Valle. El tratadista leonés incluye la vida de Velázquez en su tratado de vidas Epilogo y nomenclatura de algunos hombres famosos en esta arte, redactado entre 1656-1659, que quedó inacabado ${ }^{29}$ (Fig. 2). El autor tomó la parte principal de Pacheco, prácticamente al pie de la letra. Su propia contribución abarca el período comprendido entre el segundo viaje del artista a Italia en 1649-1651 y el posterior período en la corte madrileña hasta 1658. En el tratado la vida de Velázquez sigue a la de Rubens, precediendo a ambas las de artistas españoles como Sánchez Coello, Navarrete, Carducho y Ribera. A la vida del pintor sevillano suceden las de pintores italianos en la corte de Felipe II y de Felipe IV y artistas españoles de estas épocas. Hay que destacar que el tratadista leonés nos presenta a Velázquez mucho más integrado en el conjunto de pintores españoles que Pacheco, para el que la apreciación del artista en un ámbito europeo fue de gran importancia.

Resulta llamativo que, a diferencia de Pacheco, el genealogista no nos presente al pintor en la órbita exclusiva de artistas europeos como Rubens y Cincinato, sino también dentro del ambiente artístico español. Además de proporcionar las informaciones sobre las nueve obras de Velázquez, casi literalmente tomadas de Pacheco, Díaz del Valle menciona solamente dos retratos más de un período posterior $^{30}$. No considera relevantes los géneros de los cuadros de Velázquez. No menciona sus cuadros de historia, ni plantea el problema de su escasez, como en cambio hará Jusepe Martínez, dos décadas más tarde. Al cuadro de la «Expulsión de los moriscos bajo Felipe III» se refiere, como hiciera Pacheco, como «Retrato

29 Para Díaz del Valle, véase HELLWIG, K., «Diego Velázquez y los escritos de arte de Lázaro Díaz del Valle, en Archivo Español de Arte 67, 1994, págs. 27-41; HELLWIG, K., Op. cit. 1999; RIELLO VELASCO, J. M., Tres manuscritos de Lázaro Díaz del Valle y una nueva interpretación de sus escritos sobre pintura, en Goya 298, 2004, págs. 37-44; RIELLO VELASCO, J. M., «Un caso singular de la literatura artística española del siglo xvı: Lázaro Díaz del Valle, en La multiculturalidad en las artes y en la arquitectura, Congreso Nacional de Historia del Arte. tomo II, Las Palmas de Gran Canaria, Anroart, 2006, págs. 483-489. El tratadista leonés incluye la vida de Velázquez en los dos tratados, el «Origen e Yllustración del nobilissimo y Real Arte de la pintura», redactado de 1656-1659 y en el mucho más amplio «Epílogo y nomenclatura de algunos hombres famosos en esta arte», inacabado, cuya redacción empezó en 1656 y en cual las últimas anotaciones son del año 1662. Nos referimos aqui a la versión más amplia de la vida del pintor en el «Epílogo y nomenclatura de algunas hombres famosos en esta arte». Véase, DìAZ DEL VALLE, L., «Epílogo y nomenclatura de algunas hombres famosos en esta arte», en Varia Velazqueña, ed. Antonio Gallego y Burín, tomo II, Madrid, 1960, págs. 59-61.

30 Se trata del retrato papa Inocencio $X$ pintado durante la estancia en Roma y un retrato de Felipe IV, del cual sólo destaca que «acababa de hacer» cuando el autor redacta su texto, es decir en el año 1656. 


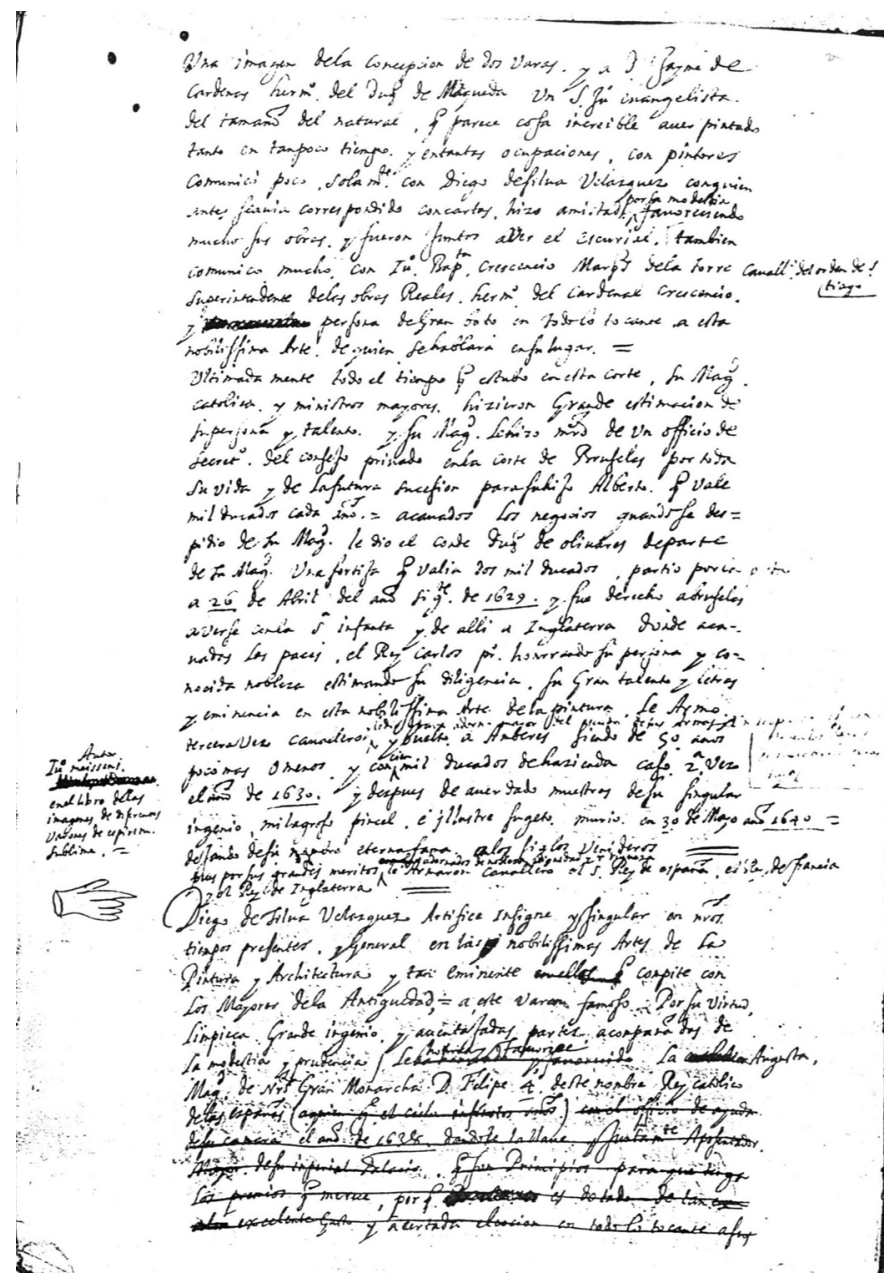

Fig. 2. Vida de Velázquez, en: Lázaro Díaz del Valle, Epilogo y Nomenclatura de Algunos Hombres famosos en este Arte, Madrid 1656-1659.

de la Mag. del glorioso Rey d Felipe 3 en un lienzo grande y la expulsión de los Moriscos de España en oposición de 3 pintores de su Mag.» Díaz del Valle, genealogista, historiador y músico no es en cambio un teórico del arte de gran formación, por lo que obviamente no muestra gran interés en adentrarse en la jerarquía de los géneros de la pintura y sus consecuencias para el rango de un pintor. 
De pintor a noble caballero: Los cambios de la imagen de Velázquez en las Vidas...

Al transcribir literalmente pasajes enteros de Pacheco, el genealogista repite la imagen de Velázquez como gran retratista y Apeles español. Pero Díaz del Valle enfatiza aún más esta imagen al mencionar dos retratos importantes, el del papa Inocencio X y el del rey Felipe IV. Subraya el éxito de Velázquez en Roma y la importancia del retrato del papa para su carrera, pues gracias a este retrato «tan al natural'» fue nombrado miembro de la Accademia di San Luca en Roma ${ }^{31}$. Además el tratadista leonés introduce un nuevo plano en la recepción de los retratos de Velázquez por el público: sus retratos no provocan solamente admiración como en Pacheco, por ser «tan al natural», sino que producen sentimientos en los espectadores. Así comenta cómo, al ver un retrato del rey, le «infundió respeto y provocó a digníssima veneración y reverencia porque no le faltaba más al retrato que la voz, porque tenía mucha alma en carne viva»32.

Hay que destacar que, a diferencia de Pacheco, Díaz del Valle no sólo presenta a Velázquez como «pintor», sino también como «profesor de este arte» ${ }^{33}$. Se basa en su puesto de «pintor de Cámara de S.M.» y en sus grandes aptidudes como retratista, mencionando que es «insigne varon en la pintura y singular en hacer retratos ${ }^{34}$. Cada vez que Díaz del Valle alude al oficio de pintor añade el de arquitecto, refiriéndose a Velázquez como «insigne artífice, pintor y arquitecto» y como «varon general y singular de nuestros tiempos presentes en los honrossissimos artes de la pintura y architectura» ${ }^{35}$.

Conviene recordar que esta ampliación de la imagen de Velázquez, de «pintor» en la vida de Pacheco a «pintor y arquitecto» en la vida de Díaz del Valle tiene un trasfondo real de su actividad en la corte de Felipe IV. En los años 1640 el artista ejerce no solamente de pintor, sino también de decorador, trazador y veedor de obras en la decoración de la Pieza ochavada del Alcázar. Es decir, que en estos años muchas de sus actividades eran muy cercanas a las de un arquitecto. El interés de Velázquez por la arquitectura es obvio si consideramos su biblioteca, en la cual además de otros escritos sobre arte tenía unos 29 tratados de arquitectura, como los de Vitruvio, Serlio o Palladio, entre otros ${ }^{36}$. Las tempranas tentativas de artista de demostrar sus facultades como arquitecto en la corte de Felipe IV se pueden leer como uno de los numerosos intentos de obtener el oficio de «Aposentador Real» y de ser nombrado "Caballero de la Orden de Santiago». Es sabido que entonces en la corte madrileña el oficio de arquitecto era mucho más es-

\footnotetext{
31 Véase DÍAZ DEL VALLE, L., Op. cit., pág. 61.

32 Véase DÍAZ DEL VALLE, L., Op. cit., pág. 61.

33 Véase DÍAZ DEL VALLE, L., Op. cit., pág. 60.

34 Véase DÍAZ DEL VALLE, L., Op. cit., pág. 61.

35 Véase DİAZ DEL VALLE, L., Op. cit., pág. 60.

${ }^{36}$ Véase SÁNCHEZ CANTÒN, F. J., «La librería de Velázquez», en Homenaje ofrecido a Menéndez
} Pidal, tomo III, Madrid, Hernando, 1925, págs. 379-406. 
timado que el de pintor, aumentando las posibilidades de obtener el puesto de «Aposentador Real». Velázquez tuvo éxito con esta política y consiguió el cargo en 1652. Llama la atención que en las actas del nombramiento del artista como Caballero de Santiago Velázquez aparezca siempre mencionado como «trazista», es decir arquitecto y apenas como «pintor» ${ }^{37}$.

Este trasfondo explica el que Díaz del Valle enfatice la faceta de Velázquez "arquitecto». Añadiendo esta actividad a la de «pintor», acentúa un mayor dominio de las artes por parte del artista, al que presenta como "varon general y singular de nros. tiempos presentes en los honrossissimos Artes de la Pintura y Architectura». Por supuesto lo hace sin precisar resultados concretos de su actividad en este campo. Se refiere solamente de modo muy general a la actividad de Velázquez como «Aposentador Real», preocupado con la disposición y adorno del Alcázar de Felipe IV y aumentando la colección - «el número de las maravillas» ${ }^{38}$. En más de un pasaje Díaz del Valle destaca el reconocimiento del ingenio del artista por pintores y arquitectos. El tratadista recoge al final de la vida, su admisión en la Academia romana con este elogio: "Tu solus didacus en orbe y esto con consentimiento de todos los Pintores y Architectos de su tiempo» 39 .

Con la citada alusión de Díaz del Valle a Velázquez como "pintor y arquitecto» entramos en el debate sobre la jerarquía de las artes tanto en la práctica como en la teoría artística española del siglo $x \mathrm{VII}{ }^{40}$. Tradicionalmente, se afirmaba la superioridad de la arquitectura sobre la pintura y escultura, pero en la práctica artística dicha jerarquía era ignorada. En los años 1630 y 1640 en la corte madrileña se fue perfilando una tendencia por la que los pintores-arquitectos y los escultores-arquitectos expulsaban a los verdaderos arquitectos de sus puestos de maestros mayores. En consecuencia se inició un virulento debate entre dos bandos. Uno lo integraban los arquitectos, representados por Juan Gómez de Mora y Francisco de Praves y el otro aquellos artistas que venían del mundo de la pintura y escultura. Entre ellos se encontraban el pintor Juan Bautista Crescenzi y los escultores Alonso Carbonel y Sebastián de Herrera Barnuevo. Este debate, sostenido en la práctica artística de palacio, existente ya en los tratados, encontró en ellos también su reflejo. Autores como Juan de Butrón y Pacheco consideraban que la pintura era el arte más elevado por el uso del dibujo, inherente a ella. Tratadistas de arquitectura como Fray Lorenzo de San Nicolás y Juan de Torija argumentaban por su parte contra el empleo de pintores y escultores como arquitectos, por fal-

37 Véanse los Documentos núm. 183, 1658-1659, en VARIA VELAZQUEÑA, tomo II, ed. Antonio Gallego y Burín, Madrid 1960, págs. 301-377.

38 Véase DìAZ DEL VALLE, L., Op. cit., pág. 61.

39 Véase DÍAZ DEL VALLE, L., Op. cit., pág. 61.

40 Véase HELLWIG, K., Op. cit. 1999, págs. 167-174, con más referencias bibliográficas. 


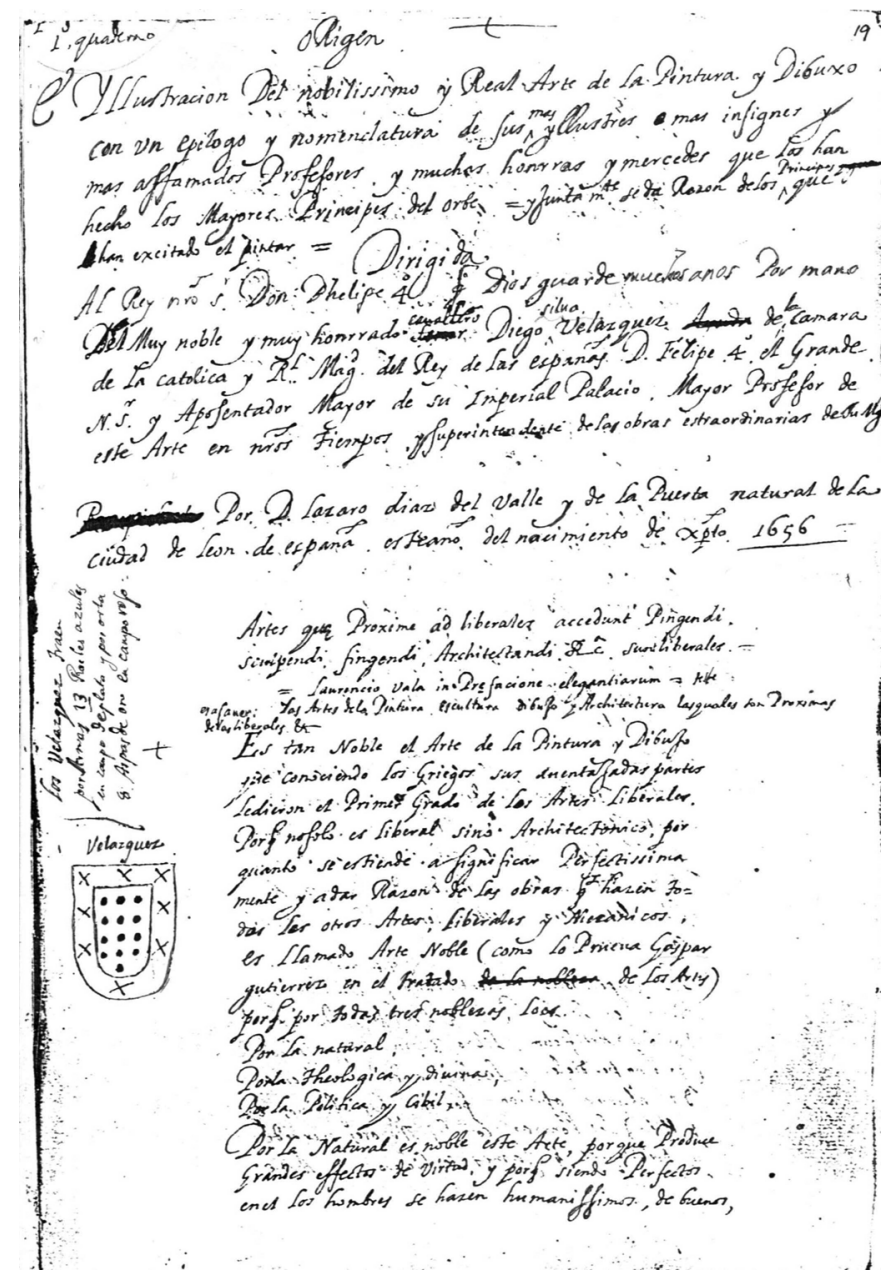

Fig. 3. Escudo de los Velázquez, en: Lázaro Díaz del Valle, Origen e Yllustración del nobilissimo y Real Arte de la Pintura, Madrid 1656.

tarles los conocimientos necesarios de estática y técnica constructiva y subrayaban una vez más la inferioridad de la pintura y escultura respecto a la arquitectura. En este contexto se enmarcan los intentos de Velázquez por establecerse como arquitecto, así mencionado por Díaz del Valle, que apoyó con el manuscrito los esfuerzos del pintor por ser nombrado caballero de Santiago.

Resulta obvia la intención de Díaz del Valle, que difiere y va más allá que la de Pacheco, de enfatizar la imagen del artista como «muy noble y muy honrrado ca- 
ballero» y como «muy virtuoso, honrrado y prudente Caballero» ${ }^{41}$. En la primera página del «Origen e Yllustración del nobilissimo y Real Arte de la Pintura» representa un escudo dibujado sobre el que escribe: «Los Velázquez traen por Armas 13 roeles azules en campo de plata y por orla ocho aspas de oro en campo rojo ${ }^{42}$ (Fig. 3). Subrayando las raíces nobles de su familia, el tratadista leonés apoya los esfuerzos de Velázquez por ingresar en la Orden de Santiago 43 . Por supuesto Díaz del Valle amplía una vez más la imagen del artista, mencionándole varias veces como «artífice» y utilizando los atributos «insigne», «milagroso», "grande y aventajado», «escojido», «famoso» hasta "divino artifice» 44 . De esta manera, el tratadista resalta sus capacidades «universales», "generales», propias de un artista que domina no sólo el arte de la pintura, particularmente de retratos, digno incluso del elogio de «divino», hasta entonces reservado a Miguel Ángel y Rafael. Colocando así a Velázquez en este círculo venerable, Díaz del Valle respalda el proceso de ennoblecimiento del sevillano.

\section{JUSEPE MARTÍNEZ: VELÁZQUEZ COMO GRAN PINTOR}

En los casi veinte años que separan el Epílogo de Díaz del Valle del tratado Discursos practicables del nobilísimo arte de la pintura, redactado por el pintor zaragozano Jusepe Martínez en 1673 (Fig. 4), la imagen de Velázquez sufre importantes modificaciones ${ }^{45}$. Martínez incluye la vida del artista en el «tratado XVI», titulado «De la estimación e inmortalidad que se debe a los profesores insignes», junto a otros pintores de corte como Bartolomé y Vicente Carducho, Félix Castelo, Alonso Cano y Juan Bautista Maíno. Esta aproximación es común a Díaz del Valle, que también había presentado a nuestro pintor en el ambiente artístico de la corte madrileña. Pero el tratadista aragonés enfatiza más el estatus de Velázquez como artista español, al renunciar a ponerle al lado de Rubens, como habían hecho Pacheco y Díaz del Valle y presentarle junto a Alonso Cano, como uno de los dos «excelentes pintores» que Olivares había traído de Sevilla a la corte ${ }^{46}$ (Fig. 5).

Sorprende que Martínez mencione solamente cinco obras concretas del pintor. Se trata de cuatro retratos - el primer retrato del rey pintado en Madrid, el retrato

41 Véase DÍAZ DEL VALLE, L., Op. cit., págs. 60-62,

42 Véase la imagen del escudo en LÓPEZ-REY, J., «Nombres y monbradía de Velázquez», en Goya, 37-38, 1960, pág. 4 y s.

${ }^{43}$ La frase final de la vida, en la que Felipe IV propone a Velázquez en 1658 que elija entre los tres hábitos de Santiago, Calatrava y Alcántara es añadida al manuscrito más tarde, de lo que se deduce que Díaz del Valle redactó el resto de la biografía antes de esa fecha.

44 Véase DÍAZ DEL VALLE, L., Op. cit., págs. 60-62,

45 Véase MARTÍNEZ, J., Op. cit., págs. 237-242.

46 Véase MARTÍNEZ, J., Op. cit., págs. 237-242. 


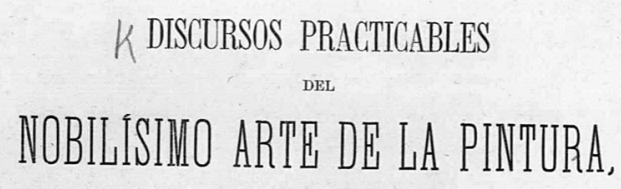

SUS RUDIMENTOS,

MEDIOS Y FINES QUB ENSEÑA LA EXPERIENCLA, CON LOS RJEMPLARES

DE OBRAS INSIGNES DE ARTÍFICES ILUSTRES,

POR JUSEPE MARTINEZ,

PINTOR DE S. M. D. FELIPE IV,

Y DEL SERMO. SR. D. JUAN DE AUSTRIA, A QUIEN DEDICA ESTA OBRA.

PUBLÍCALA LA REAL ACADEMIA DE SAN FERNANDO,

CON NOTAS, LA VIDA DEL AUTOR Y UNA RESEÑa HISTÓBTCA

DE LA PINTERA EN LA COROXA DE ARAGON,

por su individuo de número

DON VALENTIN GARDERERA Y SOLANO.

MADRID.
Imprenta de Manuel Tello, San Märcos, 26.

1866.

Fig. 4. Jusepe Martínez, Discursos practicables del nobilísimo Arte de la Pintura, Madrid, 1866.

de Inocencio X y el de doña Olimpia Pamphili, hechos en Roma («con tanta excelencia que admiraron a los que los vieron") - y el retrato de una joven, hija de un caballero de Zaragoza ${ }^{47}$. Además Martínez menciona el «Cuadro de la expulsión de los moros de España» pero, a diferencia de Pacheco y Díaz del Valle, lo hace como «historia» y no como «Retrato de Felipe III» ${ }^{48}$. Explicando las circunstancias

\footnotetext{
47 Véase MARTÍNEZ, J., Op. cit., pág. 241 y pág. 250.

48 Vease MARTíNEZ, J., Op. cit., pág. 239 y s.
} 


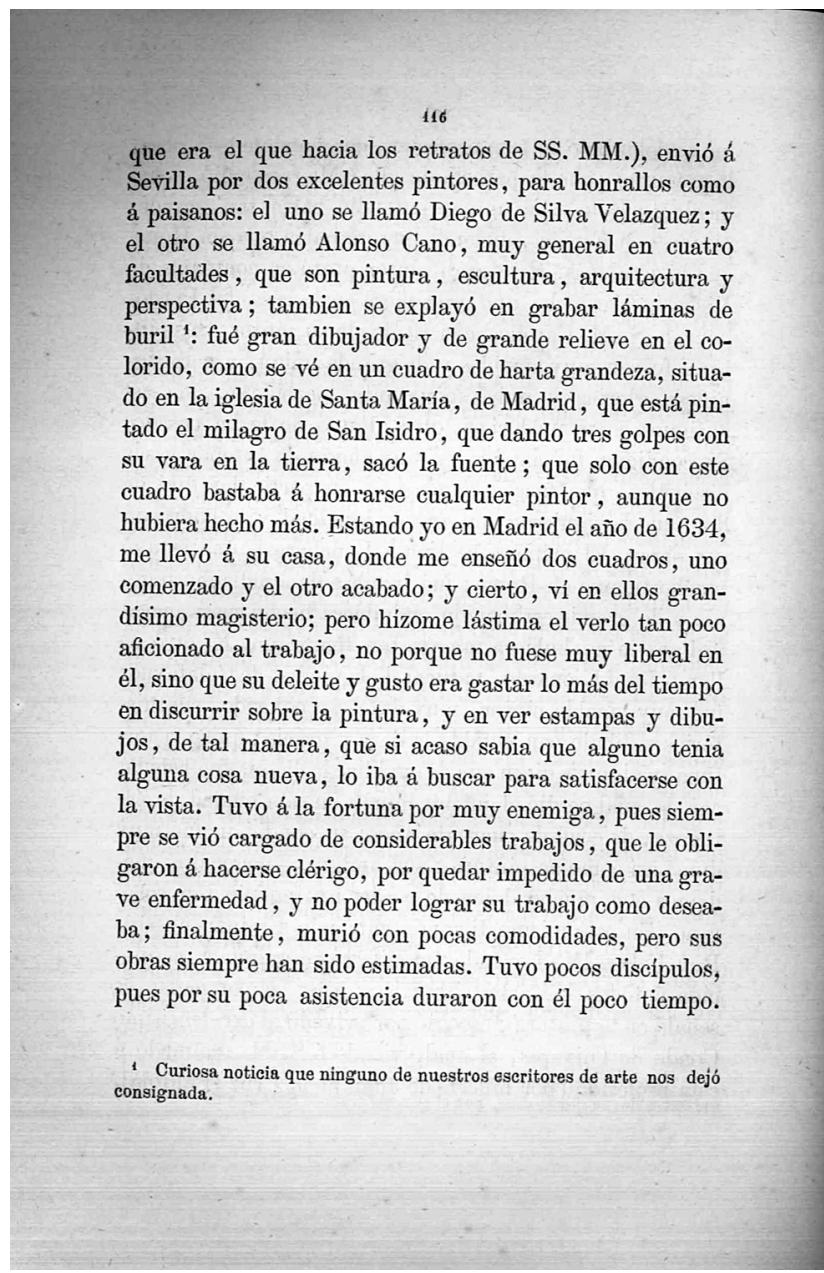

Fig. 5. Jusepe Martínez, Discursos practicables del nobilísimo Arte de la Pintura, Madrid, 1866. Vida de Velázquez (pág. 116).

del certamen de 1627, el tratadista aragonés es el primero que destaca que éste fue consecuencia de las críticas de unos «censuradores», «envidiosos» que se atrevieron a decir que Velázquez «no sabía hacer sino una cabeza». Relata cómo en el certamen compitieron cuatro pintores - añadiendo «los mejores», sin citar por supuesto los nombres - y que los cuadros se colgaron en el «Salón Mayor de Palacio». Martínez comenta el resultado subrayando que en este concurso «se conoció por esta obra la virtud de nuestro pintor, siendo el retrato muy parecido con 
De pintor a noble caballero: Los cambios de la imagen de Velázquez en las Vidas...

la historia» ${ }^{49}$. El tratadista aragonés es el primero que no sólo destaca al rey Felipe IV como comitente del cuadro de la «Expulsión de los moriscos» - lo que habían hecho ya Pacheco y Díaz del Valle- sino también el lugar donde se colgó la historia, es decir el Salón de los Espejos del Alcázar.

Además de estas cinco obras, Martínez menciona otros retratos, sin especificar los nombres de los personajes. Se trata de unos retratos realizados tras su llegada a la corte madrileña, unos «retratos a personas principales» durante su primera estancia en Roma, algunos cortesanos posteriores a dicha estancia, otros correspondientes al segundo viaje a Italia y al fin los realizados después de su regreso. El tratadista hace también referencia a historias del pintor, que tampoco especifica. Cuando destaca que Velázquez regresó de Roma «con algunas pinturas excelentes, de lo cual S.M. se dió por bien servido» ${ }^{50}$, se refiere a las grandes historias romanas, la «Fragua de Vulcano» y la «Túnica de José». Martínez afirma que, después de su segunda estancia en Roma, Velázquez continuó pintando muchos retratos, lo que explica sus escasas composiciones ${ }^{51}$. Esta alusión a las «pocas historias" de los años finales remite probablemente a los grandes cuadros de las «Hilanderas» y las «Meninas».

El tratado de Martínez es el primero en el que no sólo los retratos, sino sobre todo las historias juegan un papel importante en la carrera de Velázquez. De las recompensas citadas, únicamente obtiene dos de ellas por sus excelentes retratos. El tratadista nos relata cómo, después de hacer el primer retrato del rey, es nombrado «Pintor de Cámara» — de hecho es nombrado «Pintor del Rey», el otro oficio no lo obtendrá hasta $1628^{52}$. Y en recompensa por otros retratos pintados en la corte en los años 1620 «en virtud de ser superior a los antecedentes pintores» fue nombrado "Ujier de Cámara»53. Pero, según Martínez, Velázquez recibe las más importantes honras gracias a sus cuadros de historia. Aunque el tratadista zaragozano mencione sólo una historia en concreto, las historias juegan un papel más importante en la carrera del pintor. Por ganar el concurso con el cuadro de la «Expulsión de los moriscos» le fue concedido el título de «Ayuda de Cámara». Y el honor más grande, el nombramiento de caballero de Santiago le fue otorgado por sus «pocas historias [...] tan excelentes» pintadas después su segunda estancia en Roma. Hay que destacar que, mientras para Pacheco y Díaz del Valle el artista obtuvo todos los premios a raíz de sus excelentes retratos, en el informe de

49 Véase MARTÍNEZ, J., Op. cit., pág. 240.

50 Véase MARTíNEZ, J., Op. cit., pág. 240.

${ }^{51}$ Refiere: «no dejando proseguir en sus retratos y por eso no tuvo lugar de hacer historias; pero las pocas que hizo, salieron de tal suerte, que no contentándose S.M. con las mercedes hechas, le quiso honrar nombrándole caballero del hábito de Santiago». MARTínEZ, J., Op. cit., pág. 241.

${ }^{52}$ Véase MARTíNEZ, J., Op. cit., pág. 237.

53 Véase MARTíNEZ, J., Op. cit., pág. 239. 
Martínez las historias tienen una importancia fundamental para la carrera del pintor. Según los pasajes mencionados del tratadista aragonés, Velázquez tuvo durante toda su carrera en la corte madrileña problemas por haber pintado pocos cuadros de historia. No intenta ocultar las críticas al artista, como habían hecho Pacheco y Díaz del Valle, pero trata de desmentirlas, subrayando la importancia de estas pocas historias de Velázquez, que le habían reportado las más grandes honras.

En la vida de Martínez nos encontramos frente a una imagen de Velázquez como "pintor excelente», "pintor con más estimación", con un gran corpus de retratos hechos en la corte madrileña y en Roma. El tratadista enfatiza la actividad del pintor como retratista del rey y elogia sus retratos. Sin embargo, Martínez renuncia a los topoi utilizados por Pacheco y Díaz del Valle para presentar a Velázquez como "Apeles español». Tampoco la nobleza del artista es un tema relevante para él. Es destacable que la imagen de Velázquez como «arquitecto», tan enfatizada por Díaz del Valle veinte años antes, no aparezca en cambio en la vida de Martínez. Esta «supresión» del tratadista aragonés evidencia el fracaso del pintor de ejercer como arquitecto. Tampoco Martínez incorpora la imagen del artista como "artífice general» o "universal». Sin embargo, el tratadista sí lo hace en la vida de otros artistas como Alonso Cano, a quien nos presenta como «muy general en cuatro facultades que son pintura, escultura, arquitectura y perspectiva» ${ }^{54}$.

Uno de los objetivos de Martínez es conseguir una revaloración de los artistas españoles tanto en su propio país como en el extranjero ${ }^{55}$. Y Velázquez como pintor de gran éxito le sirve en su fin como ejemplo paradigmático. El tratadista deja muy claro las habilidades del artista en la pintura de historia, mencionando su victoria en el concurso con la «Expulsión de los moriscos» y los premios obtenidos por sus «pocas historias [...] tan excelentes». En el intento de presentar a Velázquez no solamente como "gran retratista" sino también como "gran pintor», se siente obligado a justificar las pocas historias en la obra del pintor, escasez que se explica por sus múltiples tareas en la corte y su dedicación al oficio de retratista. Destaca igualmente el papel que jugaron sus composiciones en su ascendente carrera en la corte de Felipe IV. Explica cómo los "grandes pintores» crean sus composiciones gracias a su entendimiento y especulación, sin dejar de ser, a la vez, excelentes retratistas. Del mismo modo Velázquez es para Martínez un retratista y a la vez pintor de extraordinarias historias que le convierten en un "gran pintor». Sorprende por ello que el calificativo de «gran pintor» no aparezca en la biografía de Velázquez, que sólo se deduce de la presentación de su yerno: «Entró en su lugar un yerno suyo llamado Juan Bautista del Mazo, también gran pintor» ${ }^{56}$.

\footnotetext{
54 Véase MARTÍNEZ, J., Op. cit., pág. 238.

55 Véase HELLWIG, K., Op. cit. 1999, págs. 80-93.

56 Véase MARTíNEZ, J., Op. cit., pág. 242.
} 
De pintor a noble caballero: Los cambios de la imagen de Velázquez en las Vidas...

Para el tratadista, son pocos los pintores españoles que han conseguido destacar en las historias y conseguir el estatus de "gran pintor», como lo hicieron Orfelín, Francisco Ribalta, Mazo y obviamente Velázquez ${ }^{57}$. Según Martínez, para ser reconocido como "gran pintor» Pedro Orfelín tuvo que pasar una prueba, que recuerda a la de Velázquez: sus competidores le obligaron a demostrar sus habilidades como pintor de historias. Orfelín, "grande retratador», encuentra dificultades a su vuelta de una estancia en Italia, criticado por unos artistas envidiosos que afirman que no "sabía hacer otra cosa sino retratos" ${ }^{58}$. Sólo después de mostrar sus virtudes pintando «historias para retablos y adornos de capillas» se "conoció ser gran pintor $>59$.

El hecho de que Martínez no oculte el estatus de «pintor» de Velázquez, que no intente ennoblecerle presentándole como "Apeles español», "arquitecto» 0 «noble caballero» prueba en mi opinión la estrecha relación existente entre la imagen del artista y los objetivos del tratadista, es decir, entre la teoría y la práctica pictórica. Martínez escribe la biografía de Velázquez unos 15 años después de su muerte, cuando ya no había razones para adornar su imagen como apoyo a su carrera cortesana. No tenía sentido presentarle como «Apeles español» 0 «arquitecto", desaparecidos los objetivos que habían guiado a Pacheco y Díaz del Valle. Cuando Martínez menciona su obtención del hábito de Santiago, no le interesa tanto resaltar la nobleza adquirida como la causa de tales honras: sus extraordinarias pinturas de historia. $Y$ en base a ellas logra el tratadista presentarle como «gran pintor» español.

Martínez es el creador de la imagen de Velázquez como «gran pintor», elevándole en la escala respecto a su anterior consideración de "gran retratista». Su postura se enmarca dentro del trasfondo de lucha por una mayor estimación de la pintura española. En los tratados españoles del XVII hay una fuerte reflexión sobre el menosprecio que sufre el arte español tanto aquí como en el extranjero y uno de los objetivos de los tratadistas era revalorizarlo60. En los Discursos practicables encontramos más de un pasaje en el que su autor lamenta dicha reticencia y aporta argumentos para reivindicar a los artistas nacionales. Martínez nos proporciona en sus Discursos practicables del nobilísimo Arte de la Pintura una pequeña historia de la pintura española con el objetivo de revalorizarla, para lo cual amplía el número de grandes artistas nacionales, presentando a Velázquez como paradigma del «gran pintor español».

\footnotetext{
57 Véase MARTÍNEZ, J., Op. cit., pág. 256, pág. 266 y pág. 242

58 Véase MARTÍNEZ, J., Op. cit., pág. 256.

59 Véase MARTÍNEZ, J., Op. cit., pág. 256.

60 Véase HELLWIG, K., Op. cit. 1999, págs. 80-93.
} 


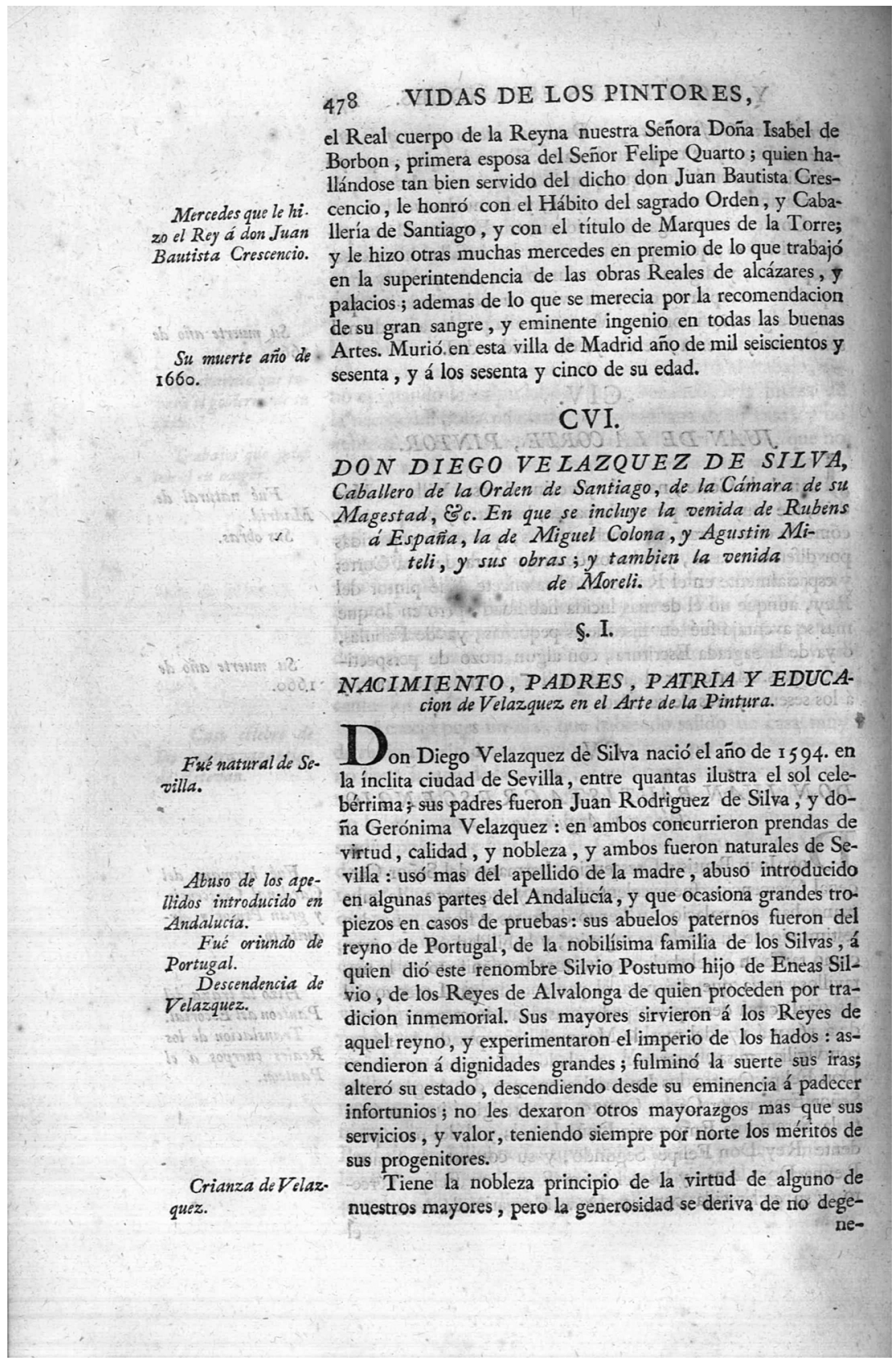

Fig. 6. Vida de Velázquez en Antonio Palomino, El Parnaso Espanol pintoresco laureado, 2. ${ }^{a}$ ed., Madrid 1797, pág. 478. 
Y ESCULTORES ESPANOLES. 479

nerar de aquella priniera naturáleza. Velazquez desde los priimeros años dió indicios de su buen natural, y de la buena sangre que estaba latiendo en sus venas, aunque en moderada fortuna; sus padres le criaron, bien que sin ornato y grandeza, con la leche del temor de Dios; aplicóse á el estudio de las buenas letras, excediendo en la noticia de las lenguas, y en la filosofía ámuchos de su tiempo. Dió muestras de particular inclinacion á pintar ; y aunque descubrió ingenio, prontitud, y docilidad para qualquiera ciencia, para esta la tenia mayor; de suérte, que los cartapacios de los estudios le servian á veces de borradores pará sus ideas. Su viveza imprimió eh los pechos de sus padres opinion muy alta de su ingenio, que despues cont el transcurso de los años desempeñó tam äventajadamente. Dexaronle seguir su inclinacion, sin que se adelantase en otros estudios, porque á estos le hallaban ya dedicado con propension natural, ó fuerza de su destino. Entregaronlé á la disciplina de Francisco de Herrera, á quien en Andalucía llaman Heriera el Viejo, hombre rígido, y de poca piedad, mas en la Pintara y orras Artes de consumado gusto. A poco tiempo dexó esta escuela, y siguió la de Franeisco Pacheco, persona de singular virtud, y de mucha erudicion, éé inteligencia en la Pintura, de la qual escribió varios libros, y compuso muy elegantes poesías, siendo celebrado de todos los escritores de su tiempo. - Era la casa de Pacheco carcel dorada del Arte, academia, y escuela de los mayores ingenios de Sevilla. $Y$ así Diego Velazquez vivia gustoso en el continuo exercicio del dibuxo, primer elemento de ta Pintura, y puerta principal del Arte. Así nos to dice el mismo Pacheco ir con la sencillez, y llaneza que acostumbra, y con la verdad de maestro. Con esta doctrind, dice, se crio mi yerno Diego Velazquez de Siloa, siendo muchacho el qual temia cohechado un aldeanillo, que le servia de modelo en diversas acciones y posfuras; ya blorando, ya riendo, sin perdonan difccultad val guna. Y hizo por él muchas de carbon, $y$ realce en papel azah, $y$ de otros muchos naturales, con cque grangeó ta certezaven el retratar. Inclinóse á pintar con singularisimo caprichos, y notable genio , animales, aves, pescaderias, y bodegones con la perfecta imitacion del natural, con bellos paises, $y$ figuras : diferencias de comida, $y$ bebida ; frutas, $y$ alhajas pobres, $y$ hümildes, con tanta valentía, dibuxo, y colorido, que parecian naturales, alzandose con esta parte, sin dexar lugar á otro, con que grangeó grande fama, y digna estimacion en sus obras, de las quales no se nos debe pasar en silencio

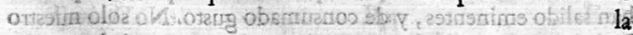

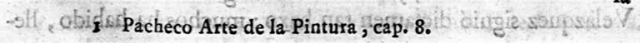

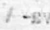

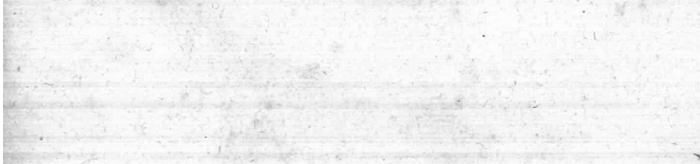

Fig. 7. Vida de Velázquez en Antonio Palomino, El Parnaso Espanol pintoresco laureado, 2. ${ }^{a}$ ed., Madrid 1797, pág. 479.

Estudios de Velazquez en las buenas letras, y filosofia.

Principios de Ve. lazquez en la Pintura en casa de Herrers el viejo.

PasaVelazquezá la escuela de Pacheco.

sis srituigy orio

Escuela de Pache-

co.
Primeros estudios
de Velazquez. 


\section{ANTONIO PALOMINO: VELÁZQUEZ COMO CORTESANO Y NOBLE CABALLERO}

Un nuevo arquetipo se establece en la minuciosa y más detallada vida de Velázquez incluida en el Parnaso español pintoresco laureado de Antonio Palomino de $1724^{61}$ (Fig. 6 y 7). Palomino evoca todas las imágenes creadas por los tratadistas anteriores, por un lado ocultando en cierto modo su papel de «pintor» y enfatizando por otro con gran perseverancia la imagen de Velázquez como «noble caballero".

\section{OBRAS CITADAS, GRAN PINTOR}

Palomino menciona en total de 52 obras de Velázquez, en su mayoría «retratos». Cita además cuatro bodegones —uno como «bodegón» y tres como «pinturas»-y nueve obras como "historia», "cuadro» o "pintura». El cordobés nos narra la génesis del primer cuadro de historia, la «Expulsión de los Moriscos por el piadoso Rey Don Felipe Tercero». Por las voces que acusaban a Velázquez de basar todas sus habilidades en "saber pintar una cabeza", se convocó un certamen, para el que «pintó esta historia en oposición de tres pintores» (Cajés, Carducho y Nardi), a los que venció según el parecer de Maíno y Crescenzi. Refiere Palomino además como historias el "célebre cuadro de los hermanos de José» y «otro cuadro, que pintó en este mismo tiempo, de aquella fábula de Vulcano", el "célebre cuadro de Cristo Crucificado difunto», "otro cuadro pintó, grandemente historiado, con el retrato de este principe, aquien enseña andar a caballo Don Gaspar de Guzmán» («Baltasar Carlos en el picadero»), «un cuadro grande historiado de la toma de una plaza por el señor Don Ambrosio Espínola» («Las Lanzas»), el "cuadro grande historiado de la Coronación de Nuestra Señora», el "cuadro grande con el retrato de la señora Emperatriz Doña Margarita María de Austria» ("Las Meninas») en el cual «lo historiado es superior» y, por último, "un cuadro de la Visita de San Antonio Abad a San Pablo Ermitaño». Con este repertorio de cuadros de historia, Palomino incluye indirectamente a Velázquez en la lista de los «grandes pintores", lo que afirma abiertamente en otro momento: "con tan soberanos testimonios de cuadros historiados había acreditado su universal comprensión del arte»62. Hay que remarcar que en ningún pasaje se alude a Velázquez como "gran pintor», ni tan siquiera aparece su oficio. Resulta algo llamativo que Palomino no utilice su propia jerarquía, desarrollada en la parte teórica del Museo

\footnotetext{
61 Véase PALOMINO, A., Op. cit. 1986, págs. 154-197.

62 Véase PALOMINO, A., Op. cit. 1986, pág. 191.
} 
De pintor a noble caballero: Los cambios de la imagen de Velázquez en las Vidas...

pictórico y escala óptica y lo aclame como «pintor perfecto», «el sexto y último grado de pintores» que crea cuadros de historia ${ }^{63}$.

Palomino presenta igualmente a Velázquez como el «Apeles español», símil antes comentado en la biografía de Pacheco ${ }^{64}$. Pero, a diferencia de éste, no lo hace solamente a través de topoi, sino de forma explícita. Ya en el segundo párrafo, referente a los inicios en la corte de Felipe IV, Palomino traza en dos ocasiones paralelos entre Velázquez y Apeles: «sólo el [Velázquez] había de retratar a Felipe IV [...] gozando la misma preheminencia que tuvo Apeles, que sólo él podía pintar la imagen de Alejandro» y, unas líneas más abajo, describe el retrato de Felipe IV a caballo «con tan airosa postura, tan arrogante y brioso que no cedía al de Apeles» ${ }^{65}$. Y después del primer viaje a Italia refiere que Felipe IV tenía la llave y silla para verle pintar despacio, «así como lo hizo el magno Alejandro con Apeles» ${ }^{66}$.

Como se ha señalado recientemente, a partir del arranque de la carrera cortesana de Velázquez, Palomino da un «quiebro radical a su discurso» y se desentiende de su obra, en pro de su carrera palatina, proceder que se enmarca dentro de la reivindicación que el tratadista hacía de la nobleza y liberalidad de la pintura $^{67}$. El tratadista relata en detalle sus tareas en la corte, sus oficios palaciegos y las honras y premios recibidos. Nada nos dice sobre sus relaciones con otros pintores, su taller o sus discípulos ${ }^{68}$. Se deduce que la carrera cortesana de Velázquez despertaba mayor interés en Palomino que la artística, a pesar de ser el pintor de un monarca tan poderoso como lo fue Felipe IV. Ya en el título de la biografía salta a la vista una diferencia entre la presentación de Velázquez y la de los otros 225 artistas del Parnaso español. Velázquez es el único artífice de las Vidas al que Palomino no añade su oficio, como sería habitual, con las palabras «Diego de Velázquez de Silva, Pintor», sino «Don Diego Velazquez de Silva, Caballero de la Orden de Santiago, de la Cámara de Su Majestad», obviando su condición de pintor ${ }^{69}$. A todos los demás maestros Palomino les presenta como «pintor», «escultor» o «arquitecto», añadiendo a veces su procedencia (Bartolomé bro IX.

63 Véase PALOMINO, A., El museo pictórico y escala óptica, tomo II, Madrid, Aguilar, 1988, aquí li-

64 Para la imagen de Velázquez como «Apeles español» en las vidas de Velázquez del siglo XVII de Pacheco y Díaz del Valle, véase HELLWIG, K., Op. cit. 1999, págs. 137-144. Para los topoi utilizados por Palomino, tomados de las vidas de los tratadistas del siglo XVII, véase MORÀN, M., «Introducción», en PALOMINO, A., Op. cit. 2008, págs. 12-14.

65 Véase PALOMINO, A., Op. cit. 1986, pág. 160.

66 PALOMINO, A., Op. cit. 1986, pág. 166.

67 Véase MORÁN, M., «Introducción», en PALOMINO, A., Op. cit. 2008, págs. 14-17.

68 Idem.

69 Véanse PALOMINO, A., Op. cit. 1986, pág. 154 y MORÁN, M., «Introducción», en PALOMINO, A., Op. cit. 2008, pág. 14. 
Vicente, pintor de Zaragoza), sus otros oficios - «presbiterio y pintor» (Diego González de Vega) - o sus títulos — «pintor de Cámara» (Francisco Ignacio Ruiz de la Iglesia), «pintor del rey» (Luca Giordano), «pintor de la reina» (Juan van Kessel), «pintor de camara del señor Carlos segundo» (Juan Carreño de Miranda)—, o el mote — «Eminente pintor llamado espagnoletto» (Jusepe Ribera).

Palomino no sólo renuncia en el título de la vida de Velázquez a presentarle como «pintor», sino que evita a lo largo de toda la biografía mencionar su oficio, que únicamente aparece unido a su cargo de «Pintor de Cámara». El tratadista sólo explica esta omisión en la vida de Juan de Alfaro, pintor cordobés, discípulo de Velázquez, a quien debe gran parte de las informaciones utilizadas en su biografía velazqueña ${ }^{70}$. Según Palomino, Alfaro negaba su condición de pintor en sus aspiraciones cortesanas, hasta el punto de que «cuando venían a su casa a preguntar, si vivía allí un pintor, respondían que no» ${ }^{71}$. Él mismo contó al tratadista cómo, en «tiempo de su maestro, [...] habían pretendido allanar la pintura con los oficios y artes mecánicas» y que si uno quería hacer carrera en la corte tenía que «desdeñarse del nombre de pintor ${ }^{72}$. Esta realidad explicaría también los motivos de Palomino, que relata en detalle las ambiciones velazqueñas en una corte en la que la pintura era considerada un oficio, por lo que era conveniente evitar nombrar la profesión de pintor.

Además de omitir su oficio de pintor en la vida del artista y detallar su carrera cortesana, llama la atención otro detalle, hasta ahora no tenido en cuenta. Palomino añade al nombre de Velázquez, ya en el título de su vida, el tratamiento de «Don». En las 105 biografías anteriores el tratadista sólo concede este trato a cinco artistas: «El reverendo padre Don Francisco Galeas Monje cartujano» (núm. 48), «Don Luis Pascual» (núm. 53), «Don Diego de Lucena» (núm. 78), «Don Juan Galban» (núm. 96) y «Don Juan Bautista Crescencio» (núm. 105)³.

Hasta que el artista obtiene sus primeras mercedes y premios en la corte, Palomino le menciona solamente con su nombre «Diego Velázquez», o «Veláz-

70 La vida de Juan de Álfaro tiene el núm. 157. Véase PALOMINO, A., Op. cit. 1986, págs. 261-265.

71 F. Ayala fue el primero en advertir este pasaje, en el que Palomino manifiesta abiertamente cómo un pintor que quería hacer carrera ocultaba su oficio. Véase AYALA, F., Op. cit., pág. 286 y s. Según Palomino, Alfaro, siguiendo su carrera en la corte como «Administrador de Rentas Reales en diferentes partidos», se vio obligado a «desdeñarse (según decían) del nombre de pintor; pues sucedió muchas veces, ir a preguntar a su casa, si vivía allí un pintor, y respondían, que no. [...] Y aún me dijo a mí, que ahora ya se podía preciar de pintor en Madrid cualquier hombre honrado; pero que antes era cosa indigna: porque en tiempo de su maestro habían pretendido allanar la pintura, y hacerla gremio, para que pagase como los oficios, y artes mecánicas; de que salió triunfante, como dijimos en el dicho tomo Cap. 3 de dicho libro.» PALOMINO, A., Op. cit. 1986, pág. 262.

72 Idem.

73 Véase PALOMINO, A., Op. cit. 1986, pág. 91, pág. 97, pág. 130, pág. 147 y p.154. 
quez» a secas. Pero cuando el pintor logra el éxito y con él los primeros oficios cortesanos, el tratadista añade a su nombre el tratamiento de «Don», tanto en los títulos de los párrafos como en el texto, salvo contadas excepciones. Este cambio en la denominación del artista me parece un detalle de gran interés, porque indica algo más sobre el papel clave que juega la vida de Velázquez en el Parnaso español pintoresco laureado: Palomino subraya con el «Don» el papel del artista español, representante afortunado de un arte liberal y noble. El modo en que Palomino utiliza dicho tratamiento en sus biografías confirma esta teoría. Si, como hemos visto, sólo cinco biografiados anteriores al sevillano merecieron el trato de «Don», en las 120 vidas que la suceden encontramos a 48 pintores que reciben tal cortesía. Evidentemente, detrás de este cambio se esconde una intención. Titulando a una gran parte de los artistas españoles de la segunda mitad del siglo XVII, empezando con Velázquez, con el «Don», el tratadista se hace eco del gran cambio que se produjo en la valoración y en el status de los artistas en España, comenzando con la fulminante carrera de Velázquez como «noble caballero», representante de un «arte liberal y noble» en la corte madrileña ${ }^{74}$.

El cambio de rango del arte de la pintura de «oficio» a «arte liberal» ocupaba ya un lugar principal en la literatura artística española del siglo $\mathrm{XVII}^{75}$. El discurso entorno a la liberalidad y nobleza de la pintura comenzó en España hacia 1600, guiado por la literatura artística italiana ${ }^{76}$. Tratadistas como Carducho y Pacheco trataban de romper el esquema de las siete artes liberales incluyendo entre ellas a la pintura. La inserción de la pintura y escultura en el sistema de las artes liberales era de gran importancia para los artistas, pues el reconocimiento de su actividad como arte liberal tenía como consecuencia mejoras económicas y sociales. Palomino sigue esta tradición en el primer tomo de su Museo Pictórico, desarrollando un gran número de argumentos a favor de la pintura como «arte liberal y noble» ${ }^{77}$. Pero, a diferencia de Carducho y Pacheco, el tratadista cordobés se centra en la realidad artística de la España del siglo XVII, mencionando numerosos pleitos y ejecutorias ganados por los artistas y los privilegios tras ellos consegui-

${ }^{74}$ Miguel Morán ha sido el primero en establecer una estrecha relación entre la vida de Velázquez y la demostración de la liberalidad de la pintura por Palomino. Véase MORÀN, M., «Introducción», en PALOMINO, A., Op. cit. 2008, págs. 12-14.

75 Véase GÁLLEGO, J., El pintor, de artesano a artista, Granada, Universidad de Granada, 1976; BROWN, J., Images and Ideas in Seventeenth-Century Spanish Painting, Princeton, N.J., Princeton University Press, 1978; PORTÙS, J., Pintura y pensamiento en la España de Lope de Vega, Hondarribia, Nerea, 1999; HELLWIG, K., Op. cit. 1999, págs. 145-174, con más referencias bibliográficas.

76 Idem.

77 Sobre la preocupación de Palomino por demostrar el caractér liberal de la pintura, véase AYALA, F., Op. cit., págs. 285-293; BASSEGODA, B., «Antonio Palomino y la memoria histórica de los artistas en España», en Arte Barroco e ideal clásico. Aspectos del arte cortesano de la segunda mitad del siglo XVII, ed. Fernando Checa Cremades, Madrid, Seacex, 2004, págs. 89-113 y MORÁN, M., «Introducción», en PALOMINO, A., Op. cit. 2008, págs. 8-10 y 12-14, con más referencias bibliográficas. 


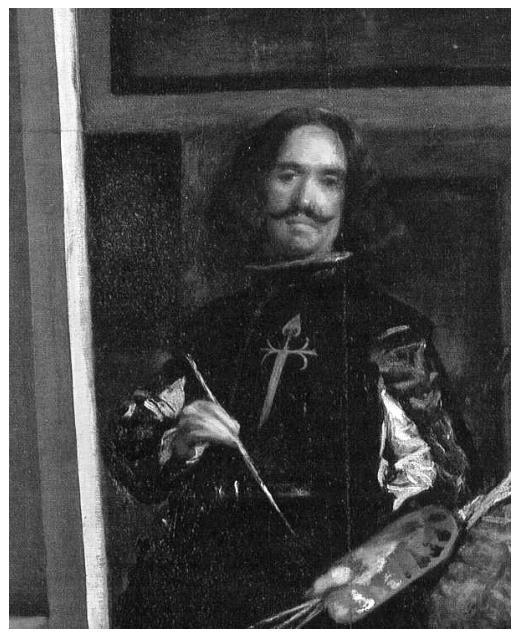

Fig. 8. Diego Velázquez, Las Meninas, Madrid, Museo del Prado, Detalle.

dos $^{78}$. Una importante consecuencia de los pleitos es que los pintores puedan ser admitidos en los «oficios del estado noble» 79 .

Palomino precisa el cambio sufrido por la condición de los pintores en su ya mencionada vida de Juan de Alfaro, que habían pasado de practicar «cosa indigna» en tiempos de Velázquez a que «ahora ya se podía preciar de pintor en Madrid cualquier hombre honrado» ${ }^{80}$. En este contexto, la afortunada carrera de Velázquez en la corte de Felipe IV de pintor a caballero de Santiago (Fig. 8), al que Palomino presenta como «Don», «noble caballero» y «vigilante vasalo», es paradigmática del cambio de estatus de la pintura en la España del XVII, reconocida como «arte liberal». A partir de Velázquez otros pintores se ennoblecieron y la mayoría de los artistas ya no fueron tratados como artesanos sino como «señores» de un «arte liberal y noble».

\section{CONCLUSIÓN}

Repasando la creación de la «imagen» es decir de las «imágenes» de Velázquez en los tratados de Pacheco, Díaz del Valle, Martínez y Palomino observamos

78 Véase PALOMINO, A., El museo pictórico y escala óptica, tomo I, Madrid, Aguilar, 1988, aquí libro II, capítulos III-V, págs. 254-292. Palomino menciona hasta siete ejecutorias ganadas por los artistas españoles a lo largo del siglo XVII.

79 Idem., pág. 289.

80 PALOMINO, A., Op. cit. 1986, pág. 261-265. 
unos cambios importantes debidos a los diferentes objetivos que les guiaron. Llama la atención que Pacheco, maestro y gran aficionado a Velázquez redacte su vida cuando su yerno apenas contaba 39 años, consagrado ya como retratista real, pero iniciando todavía su carrera cortesana a la espera de mayores honores, premios y oficios en la corte de Felipe IV. Sus escasas pinturas de historia impidieron al tratadista incluirle en la lista de "grandes pintores», pero no presentarle como "grande retratador» (al lado de Tiziano y Rubens) y como "Apeles español», apoyando sus pretensiones de obtener más mercedes, incluso un hábito de caballero. Veinte años después, Díaz del Valle, amigo y colega del artista en la corte madrileña amplía esta imagen a un Velázquez "caballero», "pintor y arquitecto» y "divino artista» con el objetivo directo de apoyar sus esfuerzos por ser nombrado Caballero de Santiago. Lo presenta así como "arquitecto» gracias a su oficio de Aposentador Real, dentro de una realidad palatina en la que el estatus de arquitecto gozaba de mayor prestigio en la jerarquía artística.

No menos destacable me parece la imagen nueva de Velázquez "gran pintor» creada por Martínez, una década después de la desaparición del artista en el apogeo de su carrera. Resulta llamativo que el tratadista aragonés renuncie a presentarnos a Velázquez como "gran retratador», "arquitecto», "Apeles español» o «noble caballero" y se centre en su carrera de pintor. Fallecido el artista en el momento de la redacción del texto, desaparecía toda necesidad de impulsar sus pretensiones cortesanas. Nos presenta a un Velázquez, no sólo «grande retratador», sino, en base a sus "pocas historias [...] tan excelentes", también "gran pintor». El tratadista zaragozano intenta confrontar el menosprecio general que sufría la pintura española dentro y fuera de las fronteras y alcanzar así una mejor valoración de los artistas nacionales. Y encuentra en Velázquez un arquetipo gracias a sus éxitos alcanzados en la corte y en Italia.

Sobre esa gran escala de imágenes de Velázquez creada por los tratadistas del siglo XVII, Palomino, sin aportar apenas novedades, pone el acento en el pintor "cortesano» y «noble caballero». Renuncia a presentarle y citarle en la biografía uniendo su oficio de pintor a su nombre, al que antepone sin embargo el tratamiento de «Don». Para el tratadista, la exitosa carrera en la corte de Felipe IV de "pintor» a "cortesano" $y$ «noble caballero» le convierte en el paradigma del cambio de estatus de la pintura, que pasa de ser "oficio» a «arte liberal» y sus artífices de "artesanos» a «profesores», pudiendo éstos dejar de maquillar su dedicación para hacer carrera en la corte.

El llamativo cambio que se produce en la imagen de Velázquez de Pacheco a Palomino en menos de 80 años, prueba la estrecha relación entre teoría y práctica artística en España y cómo la tratadística española se puso al servicio de los pintores y su arte. Los tratadistas siguen dos líneas maestras en sus biografías del ar- 
tista. Para Pacheco y Martínez, Velázquez representa un gran ejemplo por su obra de elevada calidad y su extraordinario éxito como "gran retratista», del que se valen para reivindicar el papel de la pintura española dentro y fuera del país. En cambio, para Díaz del Valle y en mayor medida para Palomino, «Don Diego Velázquez caballero" personifica, gracias a sus méritos y ennoblecimiento, el nuevo estatus alcanzado por la pintura, «arte liberal y noble» en la España de mediados del siglo XVII. 